\title{
Article \\ Encapsulated Clove Bud Essential Oil: A New Perspective as an Eco-Friendly Biopesticide
}

\author{
Zoran Milićević ${ }^{1}$, Slobodan Krnjajić ${ }^{2} \oplus$, Milan Stević ${ }^{3}$, Jovana Ćirković ${ }^{2}$, Aleksandra Jelušić ${ }^{2}$, \\ Mira Pucarević ${ }^{4}$ and Tatjana Popović ${ }^{5, *(1)}$
}

1 Field Test d.o.o., Vinogradska 150b, 11000 Belgrade, Serbia; milicevic1960@gmail.com

2 Institute for Multidisciplinary Research, University of Belgrade, Kneza Višeslava 1, 11030 Belgrade, Serbia; titanus_serbia@yahoo.com (S.K.); jovana.cirkovic@gmail.com (J.Ć.); jelusic.aleksandra@gmail.com (A.J.)

3 Faculty of Agriculture, University of Belgrade, Nemanjina 6, 11080 Belgrade, Serbia; stevicm@agrif.bg.ac.rs

4 Faculty of Environmental Protection, Educons University, Vojvode Putnika 85-87, 21208 Sremska Kamenica, Serbia; mirapucarevic@gmail.com

5 Department of Plant Diseases, Institute for Plant Protection and Environment, Teodora Drajzera 9, 11040 Belgrade, Serbia

* Correspondence: tanjaizbis@gmail.com

\section{check for}

updates

Citation: Milićević, Z.; Krnjajić, S.; Stević, M.; Ćirković, J.; Jelušić, A.; Pucarević, M.; Popović, T. Encapsulated Clove Bud Essential Oil: A New Perspective as an Eco-Friendly Biopesticide. Agriculture 2022, 12, 338. https://doi.org/ 10.3390 /agriculture12030338

Academic Editors: Mubshar Hussain, Sami Ul-Allah, Shahid Farooq and Azucena González Coloma

Received: 13 January 2022

Accepted: 24 February 2022

Published: 27 February 2022

Publisher's Note: MDPI stays neutral with regard to jurisdictional claims in published maps and institutional affiliations.

Copyright: (C) 2022 by the authors. Licensee MDPI, Basel, Switzerland. This article is an open access article distributed under the terms and conditions of the Creative Commons Attribution (CC BY) license (https:// creativecommons.org/licenses/by/ $4.0 /)$.

\begin{abstract}
In this work by encapsulation technique we have synthetized three new clove bud essential oil (CEO) Emulsifiable Concentrate (EC) formulations depending on the carrier (synthetic zeoliteF-CSZ, nature zeolite- F-CNZ and gelatin- F-CG). The main idea was to develop an eco-friendly biopesticide that can find use in plant protection as an alternative to the use of conventional pesticides. By encapsulation we wanted to enable water solubility and ensure prolonged efficacy of the essential oil. Biological activity of designed CEO formulations was tested on potato tuber moth Phthorimaea operculella (fumigant mode of action), gray mold fungal pathogen Botrytis cinerea (preserver coatings), and soft rotting bacterial pathogens Pectobacterium carotovorum (subsp. carotovorum and brasiliensis) and Dickeya dianthicola (direct competition). CEO formulations evinced a prolonged action on mortality of $P$. operculella during the insects' exposure to the concentration of the emulsions of $40 \mu \mathrm{L} \mathrm{L}^{-1}$ air. The mortality gradually decreased from a probability of $100 \%$ after the first $24 \mathrm{~h}$ to $50 \%$ after 5 days for F-CSZ or after 4 days for F-CNZ and F-CG. The most promising formulation is F-CSZ enabling activity during 14 days of exposure, while the effect of the other two formulations lasted 10 days. All three formulations produced a strong fungicidal effect against $B$. cinerea by preventing infection and disease development. The best efficacy was evidenced with F-CSZ (synthetic zeolite as a carrier) showing $100 \%$ efficacy when it was used even at the lowest tested concentration of active CEO (1\%). The results of in vitro testing against soft rot pathogens determined the MIC value of CEO formulations to be $1 \%$ of active CEO. By this research, we present a novel perspective on the use of essential oils as an alternative, environmental biopesticide. CEO formulations can be commercially exploited as a fumigant or preserver coatings to extend the shelf life of stored products or the fresh-fruit market.
\end{abstract}

Keywords: essential oil; zeolite; gelatin; encapsulation; pest control

\section{Introduction}

Plant protection products known as synthetic pesticides help in increasing the yield of food crops by controlling the loss caused by the pre- and post-harvest pests including insects, pathogens, and weeds. Estimated potential crop yield losses worldwide are $35 \%$ in the field and $14 \%$ in storage bringing the total loss of up to $50 \%$ [1-4].

Chemical-based methods of pest control in stored products are under threat for many reasons including costs, regulatory restrictions, health fears, and environmental dangers [5]. Today's global market has demanded more fresh fruits and vegetables free from pesticide residues. Combating environmental pollution and its impact on the life systems imposed 
replacement of synthetic chemicals with alternatives. Therefore, the introduction of natural pesticides, both of microbial and plant origin, is aimed to be a promising alternative to conventional pesticides.

Natural pesticides based on plant essential oils are gaining increasing attention in the food and agriculture industry [6-11]. Essential oils (EOs) have widespread use due to their antimicrobial, fungicide, insecticidal, and insect repellent activity $[6,8,12]$. Clove bud (Syzygium aromaticum L., syn. Eugenia aromaticum, E. caryophyllata, Myrtaceae family) essential oil (CEO) is known for its insecticide, antimicrobial, and nematicidal activity thanks to eugenol as the main active component [8,13-23].

Although many studies have indicated excellent antimicrobial and insecticidal properties of essential oils, their use is limited due to water insolubility, high volatility, rapid oxidation, and degradation on exposure to air [11,24]. To overcome these problems, different techniques that can provide their physical stability, protection from evaporation, and water solubility are required. Encapsulation of EOs in appropriate carriers is the most promising technique where the bioactive substance is entrapped, surrounded by a carrier matrix, which allows one to control the rate of bioactive release [3,10,24-26]. Polymer coating tends to increase oil stability and efficiency by prolonging the release rate of active components $[3,10,24,27-30]$. The most common polymers used for food ingredients encapsulation include gelatin, arabic gum, modified starches, and whey protein [10,27,31].

This research is addressed on the synthesis of new, eco-friendly formulations based on CEO encapsulation, which will improve oil solubility in water and biological efficacy by prolonging its release. Zeolites and gelatin were chosen as carriers in formulations. Designed formulations are predicted to be used in agriculture in the field of plant protection, for pests and disease control. Therefore, biological activity will be tested on selected pests and pathogens, which can be found in the open field as well as in storage conditions, (i) potato tuber moth Phthorimaea operculella Zeller [32], as one of the most destructive pests of Solanaceae, (ii) gray mold fungi pathogen Botrytis cinerea, that infects fruits (pome, stone), berries, grapes, and several vegetable species [17,30,33-35], and (iii) soft rot bacterial pathogens Pectobacterium carotovorum (subsp. carotovorum and brasiliensis) and Dickeya dianthicola destructive on a wide range of plants [36-40]. All of these harmful organisms with broad-host-range are widely present in Serbia and known to cause severe losses on attacked plant hosts. The harmfulness of P. operculella is reflected in the high level of potato tubers damage (up to the complete yield loss), as well as the complexity of its control [32]. The damages are considered to be quite significant at the locations with highest potato yields and production in Serbia [32]. Grey mold is among the most important diseases limiting fruit and vegetable production in Serbia. Total yield loss can exceed $80 \%$, especially during favorable periods for disease development (rainy and wet weather before and during harvest). Development of resistance to fungicides has become a serious problem in the control of $B$. cinerea worldwide; therefore, alternative solutions for pathogen control are required. Soft rot frequently appeared in storage conditions, primarily on potato. On potatoes in the field, these bacteria cause blackleg disease, which can reduce the yield by up to $44.7 \%$ in Serbia [39].

The present study aimed to formulate biopesticide based on the encapsulation technique of CEO using different carriers that will improve water solubility and ensure the prolonged efficacy of the oil, and to check their insecticidal (test organism P. operculella) and antimicrobial (test organisms B. cinerea, P. carotovorum, D. dianthicola) activity.

\section{Materials and Methods}

\subsection{Gas Chromatography-Mass Spectrometry (GC-MS) Analysis}

Clove essential oil (CEO) is obtained by steam distillation of clove flowers (Syzygium aromaticum) (Probotanic). In order to identify components and to determine their amounts in CEO, GC-MS analysis was performed on a GC Agilent Technologies model 6890N, equipped with an Agilent Technologies capillary HP-5MS column (60 m length; $0.25 \mathrm{~mm}$ i.d.; $0.25 \mu \mathrm{m}$ film thickness), and coupled to a mass selective detector (MSD5975B, ioniza- 
tion voltage $70 \mathrm{eV}$; all Agilent, Santa Clara, CA, USA). The carrier gas was Helium, used at a $1.2 \mathrm{~mL} \mathrm{~min}^{-1}$ flow rate. The oven temperature program was set as follows: $0 \mathrm{~min}$ at $60{ }^{\circ} \mathrm{C}$ ramped from 60 to $240{ }^{\circ} \mathrm{C}$ at $3{ }^{\circ} \mathrm{C} / \mathrm{min}$, and $5 \mathrm{~min}$ at $240{ }^{\circ} \mathrm{C}$. The chromatograph was equipped with a split/splitless injector used in the split mode with a split ratio of 50:1. Before the analysis sample was diluted with $\mathrm{EtOH}$ in ratio 1:10 $(100 \mu \mathrm{L} \mathrm{CEO}+900 \mu \mathrm{L} \mathrm{EtOH})$. The relative proportion of each component was expressed as the percentage obtained by peak area normalization, while all relative response factors were taken as one. Their Kovats indices were calculated using a homologous series of C8-C25 n-alkanes injected at the same conditions. Identification of components, in the first step, was assigned by matching their mass spectra with NIST05 Mass Spectral Library (National Institute of Standards and Technology) data with NIST MASS Spectral Search program Ver 2.0d (June 2005). Identifications were also made by comparison of their Kovats retention indices with Adams reference library file [41].

\subsection{Encapsulation}

CEO (Probotanic) formulations were prepared in the form of Emulsifiable Concentrate (EC), using three different active ingredient carriers: synthetic zeolite (FMC Foret, Barcelona, Spain), natural zeolite (ZEO-MEDIC, Belgrade, Serbia), and bovine gelatin (Sigma-Aldrich Inc., Oakville, ON, Canada). The natural zeolite mineral form clinoptilolite is used in this research, with a cation exchange capacity of $180 \mathrm{meq} / 100 \mathrm{~g}$, and particle size of $20 \mu \mathrm{m}$. The synthetic zeolite molecular Sieve type $4 \mathrm{~A}$ is an alkali alumino silicate; it is the sodium form of the Type A crystal structure. Gelatin is in the form of powder, from bovine skin, Type B (225 g Bloom).

The rapeseed oil (Granum Food, Hajdukovo, Serbia) was used as a solvent, while Tween 20 (Polysorbate 20, Aldrich-Chemie, Steinheim, West Germany) served as an emulsifier (Table 1). CEO EC formulations were prepared by mixing CEO, rapeseed oil, and Tween 20 at room temperature in a certain weight ratio as presented in Table 1 . Intensive stirring was applied after the addition of each component. Different carriers at the amount of $0.25 \%(w / w)$ were added into solutions, followed by intensive stirring, in order to obtain stable and homogeneous CEO EC formulations.

Table 1. Design of CEO EC formulations.

\begin{tabular}{ccccc}
\hline Formulation Name & Active Ingredient (\%) & Carrier (\%) & Solvent (\%) & Emulsifier (\%) \\
\hline F-CSZ & CEO (20.00) & Synthetic zeolite (0.25) & Rapeseed oil (78.75) & Tween 20 (1.00) \\
F-CNZ & CEO (20.00) & Natural zeolite (0.25) & Rapeseed oil (78.75) & Tween 20 (1.00) \\
F-CG & CEO (20.00) & Bovine gelatin (0.25) & Rapeseed oil (78.75) & Tween 20 (1.00) \\
\hline
\end{tabular}

Physical properties, commonly used for EC formulation, such as color, $\mathrm{pH}$, density, persistent foam, and ignition point were determined on CEO formulations, using the standard procedure given by WHO [42].

\subsection{Insecticidal Activity}

The insecticidal activity was tested using potato tuber moth (P. operculella) adults. Insects were collected from the potato field in the locality Maglić (Vojvodina) and then reproduced and reared in chambers under controlled conditions (temperature at $25 \pm 1{ }^{\circ} \mathrm{C}$, relative humidity $65 \pm 5 \%$, day-night cycle 16:8 h). Determination of adults was performed using external morphological characteristics. In the insect mortality tests, $0-24 \mathrm{~h}$ old moths were used. Per 20 moths were added in each glass volumetric flask (720 mL in volume).

In order to evaluate the effective concentration of pure CEO that kills 95\% (LC95) or 50\% $\left(\mathrm{LC}_{50}\right)$ of $P$. operculella adults, a procedure given by Negahban et al. was performed [43]. Five different concentrations of pure CEO corresponding to the $\mu \mathrm{L} \mathrm{L}^{-1}$ air were used: $0.5625,0.375,0.25,0.17$ and 0.11 . Each of these concentrations was dissolved in a certain amount of acetone and placed onto the filter paper strips $(5 \times 1 \mathrm{~cm})$, fixed on the lid of 
glass volumetric flasks with insects, and tightly closed. P. operculella adults were exposed to CEO vapors for the next $24 \mathrm{~h}$.

To test the prolonged release (Lethal time), adults of P. operculella were exposed to the concentration of $8 \mu \mathrm{L} \mathrm{L}^{-1}$ air of pure $\mathrm{CEO}$ and $40 \mu \mathrm{L} \mathrm{L}^{-1}$ air of encapsulated formulations for 14 days. The tested concentration was equal to the 10 times higher concentration that was determined to kill $99 \%$ of P. operculella adults after $24 \mathrm{~h}$ of treatment. Each of the three encapsulated formulations and pure CEO were applied on the filter paper strips and fixed on the lid of glass volumetric flasks with P. operculella adults, and then were tightly closed. On a daily basis, over 14 days, the treated lids were transferred to the new volumetric flasks with 20 new, $0-24 \mathrm{~h}$ old adults. The insect's mortality was determined every $24 \mathrm{~h}$ by transferring moths from the glass flasks to opened Petri dishes. During $30 \mathrm{~min}$ moths were checked if they were alive, i.e., if they can move or fly. Lethal time $\mathrm{LT}_{90}$ and $\mathrm{LT}_{50}$ were determined. A negative control was prepared without adding CEO or encapsulated formulations. The experiments were designed in a completely randomized design in four replications and were repeated twice.

\subsection{Antimicrobial Activity}

\subsubsection{Activity on Gray Mold Pathogen}

Three encapsulated CEO formulations were diluted in sterilized water in concentrations of $25 \%, 5 \%$, and $2.5 \%$, corresponding to $5 \%, 1 \%$, and $0.5 \%$ of pure CEO in solution, respectively. The solutions obtained in this way were tested for their efficacy against gray mold pathogen (B. cinerea) on raspberry (Rubus idaeus L.) fruits. B. cinerea strain MSTP-19 from laboratory collection (Faculty of Agriculture, Belgrade, Serbia) originated from raspberry was grown on Potato Dextrose Agar (PDA) at $23{ }^{\circ} \mathrm{C}$ for $8-10$ days for the experiment. The strain was identified based on the determined morphology and molecularly, using a polymerase chain reaction (PCR) method with a universal primer pair ITS1/ITS4 and sequencing afterwards.

Fresh, healthy fruits with no damage or visible disease symptoms were immersed into solutions of CEO formulations, kept there for $30 \mathrm{~s}$, and then placed on a sterile blotting sheet for $20 \mathrm{~min}$ to dry. Upon drying, the fruits were placed on Petri dishes $(\varnothing 90 \mathrm{~mm})$ at the rate of ten fruits per dish and inoculated with B. cinerea isolate MSTP-19 spore suspension $\left(2 \times 10^{5}\right.$ spore $\left.\mathrm{mL}^{-1}\right)$ using an air brush method. Petri dishes were kept at the temperature of $5{ }^{\circ} \mathrm{C}$. The experiment was performed in three replications and were repeated twice. The effects of treatments were evaluated five days after treatment, and data were rated as the number of diseased fruits per treatment.

\subsubsection{Activity on Soft Rot Pathogens}

Three soft rot causing bacteria P. carotovorum subsp. carotovorum (strain Pcc10), P. carotovorum subsp. brasiliensis (strain Pcb62) and D. dianthicola (strain Dd31) were tested in vitro for their susceptibility to CEO encapsulated formulations. All strains belong to the laboratory collection of the Institute for Plant Protection and Environment, and were originated from cabbage in case of P. carotovorum subsp. carotovorum strain Pcc10 [38], and potato in case of strains of P. carotovorum subsp. brasiliensis Pcb62 and D. dianthicola Dd31 [39]. All strains were molecularly identified [38,39]. For the experiments, strains were grown on Nutrient Agar (NA) for $48 \mathrm{~h}$ at $26^{\circ} \mathrm{C}$. The inhibitory effect was evaluated by Agar well diffusion method using holes in the medium [44]. Bacterial suspensions of the tested strains were mixed in Nutrient Agar adjusted to the final concentration of $10^{8}$ cells $\mathrm{mL}^{-1}$ and poured in sterile Petri plates $(\varnothing 90 \mathrm{~mm})$. After the media solidified, $7 \mathrm{~mm}$ diameter holes were punched with a sterile cork borer on the center of each Petri plate. CEO formulations in concentrations of $25 \%$ (equal to $5 \%$ of pure CEO), $5 \%$ (equal to $1 \%$ of pure $\mathrm{CEO}$ ), and $2.5 \%$ (equal to $0.5 \%$ of pure $\mathrm{CEO}$ ) were filled with a volume of $100 \mu \mathrm{L}$ into the well. To compare the antibacterial activity of tested concentrations of CEO formulations, pure CEO was examined at the same and higher concentrations $(10 \%, 25 \%, 50 \%$, and $100 \%)$. Plates treated with sterile distilled water served as negative 
control treatment. Petri plates were placed for incubation for three days at a temperature of $26^{\circ} \mathrm{C}$. Experiments were performed in two independent assays in three replications using a completely randomized design. The presence/absence and the diameter of inhibition halos were measured (expressed in millimeters) after three days of plates' incubation.

\subsection{Statistics}

For the pure $\mathrm{CEO}, \mathrm{LC}_{50}$ (lethal concentration to cause $50 \%$ mortality in the population) and $\mathrm{LC}_{95}$ (lethal concentration to cause $95 \%$ mortality in the population) values were calculated by probit analysis using IBM SPSS version 23 (2015). For the formulated CEO in $\mathrm{EC}, \mathrm{LT}_{50}$ (lethal time to cause $50 \%$ mortality in the population) and $\mathrm{LT}_{90}$ (lethal time to cause $90 \%$ mortality in the population) values were also calculated by probit analysis using the same statistical software. For modeling the dependence of the probability of insect mortality over time for encapsulated $\mathrm{CEO}$ or the concentration of pure $\mathrm{CEO}$, probit regression was used:

$$
\mathrm{p}_{\mathrm{i}}=\Phi\left(\beta_{0}+\beta_{1} \log _{10} x_{\mathrm{i}}\right),
$$

where $p_{i}$ is the probability of realization of the outcome encoded with 1 (mortality) at the value of the predictor of $x_{i}$ (time or concentration) and $\Phi$ is the function of the standard normal cumulative distribution. Sample estimate of this model is:

$$
\mathrm{p}_{\mathrm{i}}=\Phi\left(b_{0}+b_{1} \log _{10} x_{\mathrm{i}}\right) .
$$

For antimicrobial activity, the data were analyzed using the analysis of variance (One Way ANOVA, Statistica 7 software). The significance of differences was determinate by Duncan's multiple range $(p<0.05)$. The efficacy of tested formulations was calculated using Abbott's formula [45]:

$$
\mathrm{EF}(\%)=(\mathrm{X}-\mathrm{Y}) / \mathrm{X} \times 100
$$

where: $X=$ the number of infected fruits in the control; $Y=$ the number of infected fruits in the treatment.

\section{Results}

\subsection{CEO Chemical Composition}

GC-MS analyses of CEO (Probotanic) detected ten components accounting for $98.98 \%$ among which eugenol (4-allyl-2-ethoxyphenol) was determined as the major component with the content of $79.70 \%$, and is followed by three compounds with abundance higher than $1 \%$ (eugenol acetate, caryophyllene, caryophyllene oxide) (Table 2).

Table 2. Chemical compositions of CEO obtained by GC-MS analysis.

\begin{tabular}{cccc}
\hline Component & Content in CEO (\%) & Retention Time (min) & Kovatcs Index \\
\hline Eugenol & 79.70 & 20.9212 & 2773.6 \\
Eugenol acetate & 11.83 & 27.3963 & 3589.1 \\
Caryophyllene (E-) & 4.51 & 22.9065 & 3023.5 \\
Caryophyllene oxide & 1.37 & 29.2375 & 3821.0 \\
$\alpha$-Humulene & 0.72 & 24.2154 & 3188.5 \\
Vanillin & 0.35 & 22.0565 & 2916.6 \\
Calamene trans & 0.15 & 26.9725 & 3535.7 \\
Humilene epoxide II & 0.14 & 30.2112 & 3943.6 \\
Chavicol & 0.11 & 16.2289 & 2196.0 \\
Coniferyl alcohol (E) & 0.10 & 40.5097 & 5240.6 \\
\hline Total & 98.98 & & \\
\hline
\end{tabular}

\subsection{Encapsulated CEO Formulations}

The three different, homogeneous and stable CEO formulations were prepared in the form of Emulsifiable Concentrate (EC), using three different active ingredient carriers: 
natural zeolite (formulation named as F-CNZ), synthetic zeolite (formulation named as F-CSZ), and bovine gelatin (formulation named as F-CG).

Determined values of physical parameters of designed formulations are given in Table 3. Obtained results fulfill the criteria for EC formulation given by WHO [42].

Table 3. Physical parameters of CEO EC prepared formulations in working solution $(0.5 \%)$.

\begin{tabular}{cccc}
\hline \multirow{2}{*}{ Parameter } & \multicolumn{3}{c}{ CEO EC Formulation } \\
\cline { 2 - 4 } & F-CSZ & F-CNZ & F-CG \\
\hline Colour & yellow & yellow & yellow \\
pH & 7.6 & 7.61 & 7.65 \\
Density & $0.9158 \mathrm{~g} \mathrm{~mL}^{-1}$ & $0.9163 \mathrm{~g} \mathrm{~mL}^{-1}$ & $0.9169 \mathrm{~g} \mathrm{~mL}^{-1}$ \\
\hline Persistent foam $(0.5 \%)$ & & & \\
$10 \mathrm{~s}$ & $0 \mathrm{~mL}$ & $1 \mathrm{~mL}$ & $1 \mathrm{~mL}$ \\
$60 \mathrm{~s}$ & $0 \mathrm{~mL}$ & $0 \mathrm{~mL}$ & $0 \mathrm{~mL}$ \\
$180 \mathrm{~s}$ & $0 \mathrm{~mL}$ & $0 \mathrm{~mL}$ & $0 \mathrm{~mL}$ \\
$720 \mathrm{~s}$ & $0 \mathrm{~mL}$ & $0 \mathrm{~mL}$ & $>100^{\circ} \mathrm{C}$ \\
\hline Ignition point & $>100^{\circ} \mathrm{C}$ & $>100{ }^{\circ} \mathrm{C}$ &
\end{tabular}

\subsection{Insecticidal Activity}

Exposing of $P$. operculella to five concentrations of pure CEO for $24 \mathrm{~h}$ resulted in lethal concentrations of $0.225 \mu \mathrm{L} \mathrm{L}^{-1}$ air to cause mortality of $50 \%\left(\mathrm{LC}_{50}\right)$ and $0.536 \mu \mathrm{L} \mathrm{L}^{-1}$ air to cause mortality of $95 \%\left(\mathrm{LC}_{95}\right)$ of $P$. operculella adults (Table 4$)$. The concentration of $0.768 \mu \mathrm{L} \mathrm{L}^{-1}$ air killed $99 \%$ of $P$. operculella adults after $24 \mathrm{~h}$ exposure.

Table 4. The lethal concentrations $\left(\mu \mathrm{L} \mathrm{L}^{-1}\right)$ of pure CEO and the lethal time (day) of encapsulated CEO EC formulations with an appropriate confidence intervals, chi, and $p$-values.

\begin{tabular}{|c|c|c|c|c|c|c|c|c|c|c|}
\hline Samples & $\mathrm{LC}_{50}$ & $\mathrm{CI}_{50}$ & $\mathrm{LC}_{95}$ & $\mathrm{CI}_{95}$ & $\mathbf{L T}_{50}$ & $\mathrm{TI}_{50}$ & $\mathbf{L T}_{\mathbf{9 0}}$ & $\mathrm{TI}_{90}$ & Chi & $p$ \\
\hline $\begin{array}{l}\text { Pure } \\
\text { CEO }\end{array}$ & 0.225 & $0.208-0.243$ & 0.536 & $0.466-0.645$ & - & - & - & - & 7.435 & 0.998 \\
\hline F-CSZ & - & - & - & - & 5.898 & $5.539-6.243$ & 0.954 & $0.210-1.576$ & 30.762 & 0.995 \\
\hline F-CNZ & - & - & - & - & 4.341 & $4.031-4.635$ & 0.765 & $0.112-1.294$ & 26.718 & 0.915 \\
\hline F-CG & - & - & - & - & 4.472 & $4.189-4.744$ & 1.220 & $0.652-1.683$ & 19.856 & 0.993 \\
\hline
\end{tabular}

To test the prolonged-release, treatment with pure CEO provided $100 \%$ mortality of P. operculella adults after $24 \mathrm{~h}$ exposure. After $48 \mathrm{~h}$, mortality was not determined, i.e., CEO lost insecticidal activity. When the three encapsulated CEO EC formulations were used, a prolonged action on P. operculella adults mortality was recorded. During the insects' exposure to the emulsion concentration of $40 \mu \mathrm{L} \mathrm{L}^{-1}$ air, the mortality gradually decreased from a probability of $100 \%$ after the first $24 \mathrm{~h}$ to $50 \%$ after 5 days for F-CSZ or after 4 days for F-CNZ and F-CG. The most promising formulation is F-CSZ enabling activity during 14 days of exposure, while the effect of the other two formulations (F-CNZ, F-CG) lasted 10 days. For all three CEO formulations, the insect mortality rate was higher than $50 \%$ after four days of $P$. operculella adults' exposure.

\subsection{Antimicrobial Activity}

B. cinerea isolate caused gray mold symptoms on inoculated raspberry fruits in the control treatment. Experimental data revealed completely reduced (100\%) infection of raspberry fruits when $5 \%$ active ingredient (CEO) was applied for all three formulations (Table 5). When formulations were applied in a concentration equal to $1 \%$ of pure CEO, formulations with zeolite as the carrier (F-CSZ and F-CNZ) showed a 100\% efficacy, while formulation with gelatin (F-CG) reduced the disease for $93.4 \%$. Use of concentration equal to $0.5 \%$ of CEO was $100 \%$ effective only for F-CSZ formulation, while other two 
CEO formulations showed reduced efficacy of $93.4 \%$ and $66.7 \%$ for F-CNZ and F-CG, respectively (Table 5). The best efficacy was evidenced with F-CSZ (synthetic zeolite as the carrier), showing $100 \%$ efficacy when it was used, even at the lowest tested concentration of active CEO. A statistically significant difference was found in the treatment with the CEO concentration of $0.5 \%$ between zeolite-carrier formulations (F-CSZ and F-CNZ) and gelatin-carrier formulation F-CG (Table 5).

Table 5. Efficacy of encapsulated CEO formulations used on raspberry fruits against B. cinerea.

\begin{tabular}{|c|c|c|c|c|c|c|c|}
\hline \multirow{2}{*}{$\begin{array}{c}\text { Formulation } \\
\text { Name }\end{array}$} & \multirow{2}{*}{$\begin{array}{c}\text { Working } \\
\text { Concentration (\%) }\end{array}$} & \multirow{2}{*}{$\begin{array}{c}\text { Equal Concentration of } \\
\text { CEO }(\%)\end{array}$} & \multicolumn{3}{|c|}{ Replicate * } & \multirow{2}{*}{ Average } & \multirow{2}{*}{ Efficacy (\%) } \\
\hline & & & $\mathbf{I}$ & II & III & & \\
\hline \multirow{3}{*}{ F-CSZ } & 25 & 5 & 0 & 0 & 0 & $0 \mathrm{a}$ & 100 \\
\hline & 5 & 1 & 0 & 0 & 0 & $0 \mathrm{a}$ & 100 \\
\hline & 2.5 & 0.5 & 0 & 0 & 0 & $0 \mathrm{a}$ & 100 \\
\hline \multirow{3}{*}{ F-CNZ } & 25 & 5 & 0 & 0 & 0 & $0 \mathrm{a}$ & 100 \\
\hline & 5 & 1 & 0 & 0 & 0 & $0 \mathrm{a}$ & 100 \\
\hline & 2.5 & 0.5 & 0 & 1 & 1 & $0.67 \mathrm{a}$ & 93.4 \\
\hline \multirow{3}{*}{ F-CG } & 25 & 5 & 0 & 0 & 0 & $0 \mathrm{a}$ & 100 \\
\hline & 5 & 1 & 1 & 0 & 1 & $0.67 \mathrm{a}$ & 93.4 \\
\hline & 2.5 & 0.5 & 3 & 3 & 4 & $3.3 \mathrm{~b}$ & 66.7 \\
\hline Control & - & - & 10 & 10 & 10 & $10.0 \mathrm{c}$ & 0 \\
\hline
\end{tabular}

* number of fruits with gray mold symptom from a total of 10 per replicate; values followed by the same letter within columns are not significantly different $(p<0.05)$; Duncan test $>\mathrm{MS}=0.1111 ; \mathrm{df}=18$.

In vitro testing of antibacterial activity of encapsulated formulations and pure CEO determine the concentration of $1 \%$ to evince inhibitory effect against soft rot bacteria growth (P. carotovorum subsp. carotovorum, P. carotovorum subsp. brasiliensis, D. dianthicola) (Figure 1). CEO EC formulations exhibited a similar antibacterial activity in tested concentrations compared with the same concentrations of pure CEO. The concentration of $1 \%$ active CEO was determined to be a minimal inhibitory concentration (MIC) for both encapsulated formulations and pure $\mathrm{CEO}$. From the results obtained by the testing of higher concentrations of pure CEO (Figure 1d), it is evident that CEO expressed an almost similar efficacy when used in an undiluted form and reduced concentrations until 5\%. These results indicate that the increase of $\mathrm{CEO}$ concentration is not in correlation with the efficacy, meaning that a similar trend in efficacy was obtained when $\mathrm{CEO}$ was used in undiluted form and in reduced concentrations till $10 \%$. 

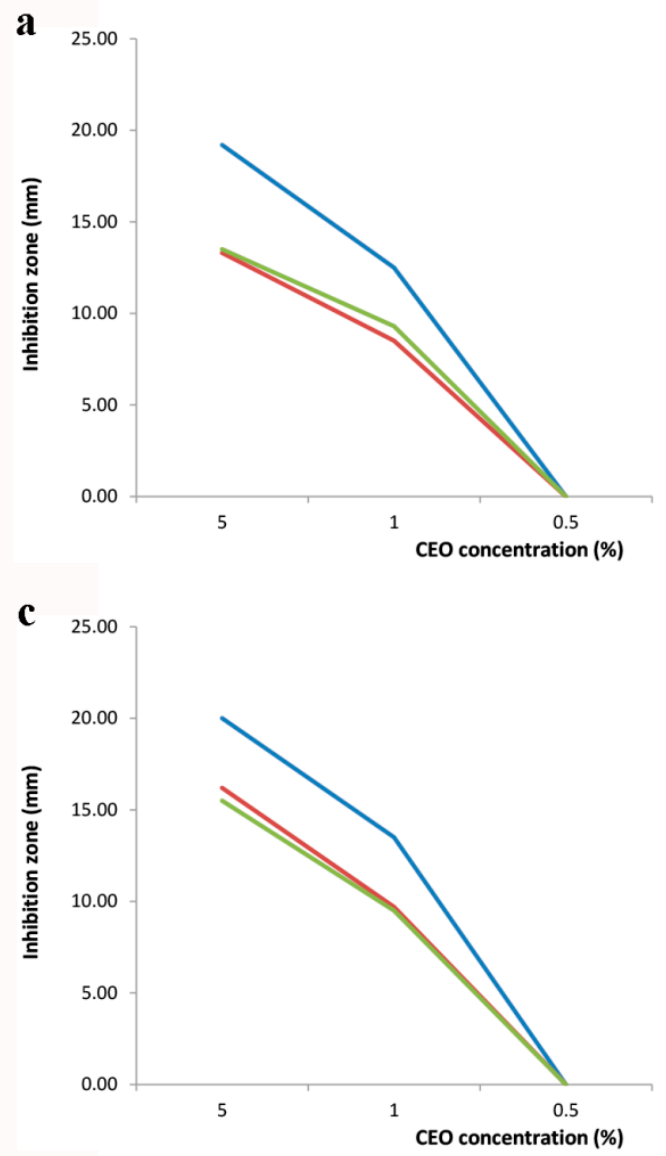

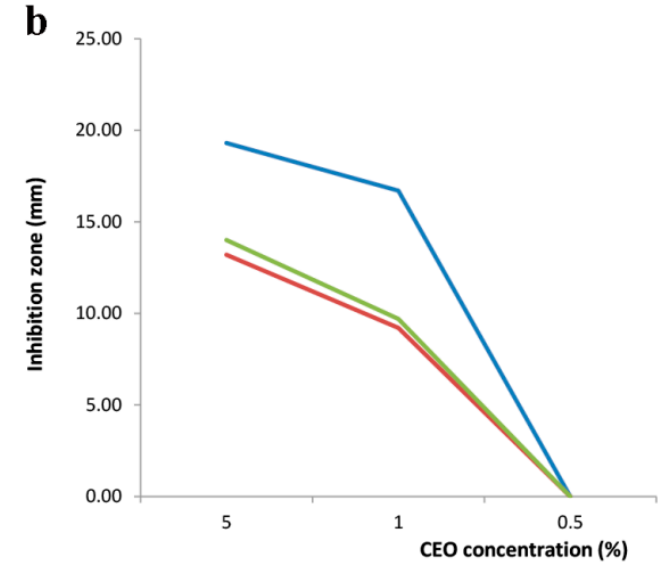

d
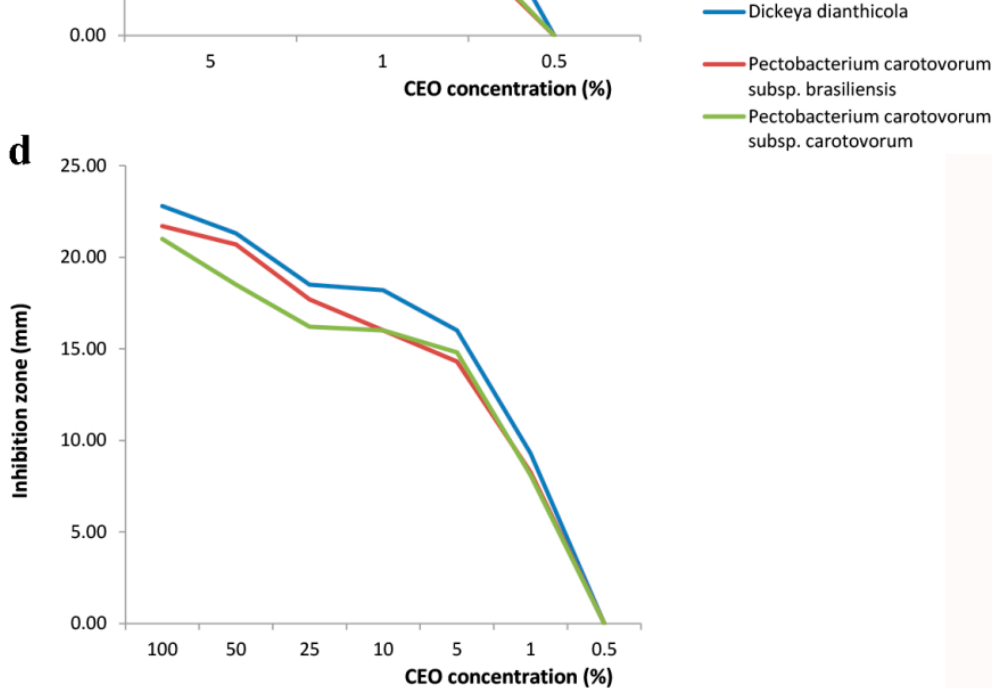

Figure 1. In vitro antibacterial activity of encapsulated and pure CEO against soft rot bacteria; (a) FCNZ; (b) F-CSZ; (c) F-CG; (d) pure CEO.

\section{Discussion}

Instead of using synthetic pesticides, this study is considering a solution for reducing post-harvest insect and pathogen losses with the CEO EC formulations with the aim to have chemical-free, uncontaminated products during storage time. Some of the most harmful storage organisms in Serbia are potato tuber moth P. operculella, gray mold pathogen ( $B$. cinerea) and soft rot pathogens (Pectobacterium spp. and Dickeya spp.) Many pesticides are withdrawn from the global market, and their use was prohibited on any plant products such as fruit and vegetables. In contrast, the market of biopesticides is increasing. They are derived from plant, microbial, or mineral origin acting via competition, production of antibiotics, parasitism or induction of plant defense. In this work, we designed three new, eco-friendly CEO formulations with the main idea to improve the bioactivity of oil by enabling its slow release and solubility in water. We choose CEO because it was determined to have a high efficacy against insects and plant pathogens in preliminary testing. Formulations are differing in the used carriers. Bovine Gelatin serves as a polymer matrix where CEO lipid droplets remain embedded. Zeolite adsorbs CEO droplets due to its porosity. Additives, such as Tween 20, are used as surfactants for CEO droplets dispersing in solution. The idea for gelatin arose from our previous work [46] where it was proven as a well exploited career for lemongrass EO. Zeolites were chosen for use because of their ability to control emissions and adsorption capacity for low volatile organic compounds concentrations, thus making them more suitable for working with low end concentrations than activated carbon or polymer [47]. According to De Smedt et al., zeolites can be applied as particle films against pests and diseases and can act as carriers of different active substances, ensuring slow-release applications [48]. Consequently, our assumption was to test zeolites as carriers in CEO formulations and to compare them with formulations 
where the well-known carrier gelatin (polymer) was used. Some researchers used natural zeolite, clinoptilolite, as a carrier for pesticides, such is the case with a solid form of the synthetic pyrethroid insecticide supercypermetrine [49] or for biology agents such is case of photostabilisation of Bacillus thuringiensis [50].

The choice of the material used as a coating or carrier for the encapsulation of EOs is crucial; it must protect the oil, guarantee its controlled release, be water-soluble, biocompatible, and biodegradable [31]. Four categories of compounds are reported to be used to obtain edible polymers: hydrocolloids (proteins and polysaccharides), polypeptides, lipids, and composites [31].

Encapsulation of EOs is, in general, a promising technique for the protection of sensitive bioactive compounds from degradation. Consequently, many researchers who developed several methods such as: films, microencapsulation via spray-drying, nanoprecipitation, electrohydrodynamic processes electrospinning, and electrospraying [51-53]. Encapsulation is most widely used in the food industry [31,51,52], but can find use in the pharmaceutical sector [53], and in some cases in plant protection [46,54]. Using different techniques and/or carriers, many EOs were encapsulated, such are Basil, Cinnamon, Carvacrol, Jasmine, Lime, Thyme, Lemon, Lemongrass, Orange, Oregano, Peppermint, Rosemary, etc. [46,52-55] Jovanović et al. developed a biodegradable, eco-friendly material based on natural polymers and lemongrass (Cymbopogon citratus L.), and essential oil (LEO) for application as a green pesticide against the potato tuber moth (P. operculella) [46]. Thyme was encapsulated by spray drying and evaluated for efficacy on the mortality and persistence of corn weevil Sitophilus zeamais [54]. Hill et al. microencapsulated inclusion complexes of Cinnamon bark extract, trans-cinnamaldehyde, clove bud extract, eugenol, and a trans-cinnamaldehyde:eugenol (2:1) mixture by freeze-drying [28]. These complexes were effective at lower active compound concentrations than free oils, likely due to their increased water solubility, which led to increased contact between pathogens and EOs. Kouassi et al. incorporated Cinnamomum zeylanicum into commercial citrus waxes (shellac, carnauba, paraffin, and polyethylene) and achieved excellent biological activity with shellac and/or carnauba wax formulations [56]. Encapsulated EOs are promising agents that can be used to increase the antimicrobial and pesticidal activities of EOs in real food systems [10]. The increased bioactivity of essential oils in the encapsulation matrix compared to free oil, even at the same or a lower concentration, was reported [10].

In the present study, we analysed the chemical composition of the CEO (Probotanic). Eugenol was detected as a major compound. Eugenol was also previously reported as a main compound of CEO in the range from $45-90 \%$ [18,19,57,58]. Tested CEO (Probotanic) was used for encapsulation, matched to a complex of compounds that are under optimum concentration ranges. Differences in the chemical composition of the CEO can vary depending on the climatic, seasonal, and/or geographic conditions, or the plant part they are extracted from. The significant variations in the content of the main compounds can be correlated to different harvest seasons [59]. Eugenol's antimicrobial activity is based on the ability to permeabilize the cell membrane and interact with proteins $[58,60]$, hence its high content is desirable in CEO. Eugenol demonstrated contact toxicity and affected the food consumption and growth of stored-product insects [61].

Our idea was to check different modes of action of CEO formulations on target organisms; therefore, for insects, we demonstrated a fumigant mode of action. For fungal pathogens, we checked their acting as preserver coatings to extend the shelf life of stored products, and the direct inhibitory effect on the pathogen growth was checked in the case of bacterial pathogens (in vitro assay). In our study, the CEO concentration of $0.768 \mu \mathrm{L} \mathrm{L}^{-1}$ air was found to kill $99 \%$ of P. operculella adults after $24 \mathrm{~h}$ of exposure. When encapsulated CEO formulations were used, 14 days of prolonged action was determined for F-CSZ, and 10 days for the other two, F-CNZ and F-CG. Similarly, in other study, encapsulated lemongrass formulation showed the insecticidal and prolonged effect for up to seven days against the potato tuber moth [46]. The CEO was shown to be promising for applications in insect control. Insecticide potential of CEO for pest control whether by contact, repellence 
or fumigation is stated by many researchers [57,62]. According to Jairoce et al., CEO caused $100 \%$ mortality of bean and maize weevils using concentrations of 17.9 and $35 \mu \mathrm{L} \mathrm{g}^{-1}$, with $\mathrm{LC}_{50}$ ranging from $9.45-10.15 \mu \mathrm{L} \mathrm{g}^{-1}$ [22]. Similarly, Tian et al. showed that CEO exhibited strong contact toxicity against Cacopsylla chinensis and the reduced population for $73.01 \%$ (with dose $4.80 \mathrm{mg} \mathrm{mL}^{-1}$ ), $66.18 \%$ (with dose $2.40 \mathrm{mg} \mathrm{mL}^{-1}$ ), and $46.56 \%$ (with dose $\left.1.20 \mathrm{mg} \mathrm{mL}^{-1}\right)$ [21].

The determination of gray mold decontamination of raspberry fruits after treatment with encapsulated CEO EC formulations showed that they can reduce the infection and prolong the disease-free period of fruits. According to the obtained results, we can recommend commercial coatings enriched with CEO EC formulations of fruit, berry, grape, or vegetable pre-storage applications, as an effective control treatment against the gray mold pathogen. The efficacy of different essential oils for in vivo stone fruit postharvest treatment in the control of $B$. cinerea was reported $[4,33,34,63,64]$. Siripornvisal et al. reported antifungal properties of CEO against $B$. cinerea mycelial growth [17]. Daniel et al. found that after direct exposure of apples for $B$. cinerea management, $C E O$ and garlic extracts have a curative effect, either when used individually or in combination, and are proven to be more effective than a protective application [35]. Control of the gray mold pathogen is possible using Zataria multiflora encapsulated in chitosan nanoparticles [30] or Rosmarinus officinalis (rosemary) and Mentha piperita (peppermint) individually, or in combination with hypobaric treatment at $50 \mathrm{kPa}$ [65]. Some commercial formulations containing thymol and carvacrol as active ingredients inhibited the mycelium growth and spore germination of $B$. cinerea [34].

The CEO is known to be effective against soft rot bacteria [36-38], as well as in general against both Gram-positive and Gram-negative bacteria [57]. We found that MIC (or minimum bactericidal concentrations, $\mathrm{MBC}$ ) of $\mathrm{CEO}$ was $1 \%$ concentration in controlling soft rot pathogens. $\mathrm{CEO}$ with $\mathrm{MBC} / \mathrm{MIC}=1-2$ and eugenol with $\mathrm{MBC} / \mathrm{MIC}=1-4$ were bactericidal for seven Gram-negative and nine Gram-positive fish pathogenic bacteria [66]. Hajian-Maleki et al. conducted research to exploit an innovative approach for potato soft rot disease management by application of three novel EOs extracted from indigenous plants including Hyssopus officinalis, Satureja khuzistanica, and Zataria multiflora under in vitro and in vivo conditions [67]. The highest suppressive effects were displayed by S. khuzistanica and Z. multiflora with MIC at 0.19 and $0.38 \mathrm{~g} \mathrm{~L}^{-1}$. The results of the in vivo trial indicated that tuber rot development was more efficiently controlled in preventive than in curative conditions. Disease incidence was reduced by $38.4-70.6 \%$ as compared with non-coated samples in preventing assessment.

Current research suggests that CEO and encapsulated EC formulations for their application as natural, eco-friendly biopesticides are an integral part of a new approach to pest and disease control.

\section{Conclusions}

Within this study, we successfully synthesized three new stable and homogenous CEO EC formulations based on natural biopolymers such as gelatine; zeolite and clove bud essential oil, that fulfill physical properties according to the criteria for the practical usage as a biopesticide. CEO encapsulated in EC formulations provides an environment-friendly alternative to synthetic pesticides in pest and pathogen control management strategies by demonstrating a high biological efficacy against $P$. operculella by providing prolonged oil efficacy of up to 14 days. This is a significant improvement, since the pure CEO lost the bioactivity against the insects after the first day of action. All three CEO formulations showed a fungicidal and bactericidal effect against gray mold and soft rot pathogens, respectively. By enabling better and prolonged oil efficacy without affecting fresh produce quality and storage, CEO formulations can be commercially exploited as fumigant or preserver coatings to extend the shelf life of stored products or the fresh-fruit market. Further work should be focused on experiments in pre-harvest production, to evaluate its possible use, efficiency, and economic justification. 


\begin{abstract}
Author Contributions: Conceptualization, T.P., S.K. and M.P.; Methodology, Z.M., S.K. and T.P.; software, S.K., M.S. and T.P.; validation, S.K., M.P. and T.P.; formal analysis, Z.M., S.K., M.S. and T.P.; investigation, Z.M., S.K., M.S., A.J. and T.P.; resources, Z.M. and T.P.; data curation, Z.M., S.K., M.S. and T.P.; writing—original draft preparation, Z.M. and T.P.; writing-review and editing, S.K., J.Ć., M.S., M.P. and A.J.; visualization, J.Ć., A.J. and M.P.; supervision, T.P.; funding acquisition, Z.M., S.K. and T.P. All authors have read and agreed to the published version of the manuscript.
\end{abstract}

Funding: This research received no external funding.

Institutional Review Board Statement: Not applicable.

Informed Consent Statement: Not applicable.

Data Availability Statement: Not applicable.

Acknowledgments: This work was partially supported by the Ministry of Education, Science and Technological Development of the Republic of Serbia. We greatly appreciate and thank Zora Žagar for helping us in designing formulations.

Conflicts of Interest: The authors declare no conflict of interest.

\title{
References
}

1. Pimentel, D.; McLaughlin, L.; Zepp, A.; Lakitan, B.; Kraus, T.; Kleinman, P.; Selig, G. Environmental and Economic Effects of Reducing Pesticide Use: A substantial reduction in pesticides might increase food costs only slightly. Bioscience 1991, 41, 402-409. [CrossRef]

2. Oerke, E.C. Crop losses to pests. J. Agric. Sci. 2006, 144, 31-43. [CrossRef]

3. Devi, N.; Maji, T.K. Neem seed oil: Encapsulation and control. In Pesticides in the Modern World-Pesticides Use and Management; Stoytcheva, M., Ed.; In Tech: Rijeka, Croatia, 2011; pp. 191-232.

4. Zamani-Zadeh, M.; Soleimanian-Zad, S.; Sheikh-Zeinoddin, M.; Goli, S.A.H. Integration of Lactobacillus plantarum A7 with thyme and cumin essential oils as a potential biocontrol tool for gray mold rot on strawberry fruit. Postharvest Biol. Technol. 2014, 92, 149-156. [CrossRef]

5. Moore, D.; Lord, J.C.; Smith, S.M. Pathogens. In Alternatives to Pesticides in Stored-Product IPM; Subramanyam, B., Hagstrum, D., Eds.; Kluwer Academic: New York, NY, USA, 2000; pp. 193-228.

6. Isman, M.B. Plant essential oils for pest and disease management. Crop Prot 2000, 19, 603-608. [CrossRef]

7. Isman, M.B. Botanical insecticides, deterrents, and repellents in modern agriculture and an increasingly regulated world. Annu. Rev. Entomol. 2006, 51, 45-66. [CrossRef]

8. Bakkali, F.; Averbeck, S.; Averbeck, D.; Idaomar, M. Biological effects of essential oils-a review. Food Chem. Toxicol. 2008, 46, 446-475. [CrossRef] [PubMed]

9. Koul, O.; Walia, S.; Dhaliwal, G.S. Essential oils as green pesticides: Potential and constraints. Biopestic. Int. 2008, 4, 63-84.

10. Majeed, H.; Bian, Y.Y.; Ali, B.; Jamil, A.; Majeed, U.; Khan, Q.F.; Fang, Z. Essential oil encapsulations: Uses, procedures, and trends. RSC Adv. 2015, 5, 58449-58463. [CrossRef]

11. Bakry, A.M.; Abbas, S.; Ali, B.; Majeed, H.; Abouelwafa, M.Y.; Mousa, A.; Liang, L. Microencapsulation of oils: A comprehensive review of benefits, techniques, and applications. Compr. Rev. Food Sci. Food Saf. 2016, 15, 143-182. [CrossRef]

12. Kumar, R.; Srivastava, M.; Dubey, N.K. Evaluation of Cymbopogon martinii oil extract for control of postharvest insect deterioration in cereals and legumes. J. Food Prot. 2007, 70, 172-178. [CrossRef]

13. Taniwiryono, D.; Berg, H.; Riksen, J.A.G.; Rietjens, I.M.C.M.; Djiwantia, S.R.; Kammenga, J.E.; Murk, A.J. Nematicidal activity of plant extracts against the root-knot nematode, Meloidogyne incognita. Open Nat. Prod. J. 2009, 2, 77-85.

14. Meyer, S.L.; Lakshman, D.K.; Zasada, I.A.; Vinyard, B.T.; Chitwood, D.J. Phytotoxicity of clove oil to vegetable crop seedlings and nematotoxicity to root-knot nematodes. HortTechnology 2008, 18, 631-638. [CrossRef]

15. Elnabawy, E.S.M.; Hassan, S.; Taha, E.K.A. Repellent and Toxicant Effects of Eight Essential Oils against the Red Flour Beetle, Tribolium castaneum Herbst (Coleoptera: Tenebrionidae). Biology 2022, 11, 3. [CrossRef] [PubMed]

16. Kačániová, M.; Galovičová, L.; Borotová, P.; Valková, V.; Ďúranová, H.; Kowalczewski, P.Ł.; Said-Al Ahl, H.A.H.; Hikal, W.M.; Vukic, M.; Savitskaya, T. Chemical Composition, In Vitro and In Situ Antimicrobial and Antibiofilm Activities of Syzygium aromaticum (Clove) Essential Oil. Plants 2021, 10, 2185. [CrossRef] [PubMed]

17. Siripornvisal, S.; Rungprom, W.; Sawatdikarn, S. Antifungal activity of essential oils derived from some medicinal plants against grey mould (Botrytis cinerea). Asian J. Food Ag-Ind. 2009, 2, S229-S233.

18. Nurdjannah, N.; Bermawie, N. Cloves. In Handbook of Herbs and Spices, 2nd ed.; Peter, K.V., Ed.; Woodhead Publishing: Cambridge, UK, 2012; pp. 197-215.

19. Barakat, H. Composition, antioxidant, antibacterial activities and mode of action of clove (Syzygium aromaticum L.) buds essential oil. Brit. J. Appl. Sci. Technol. 2014, 4, 1934-1951. [CrossRef]

20. Hamini-Kadar, N.; Hamdane, F.; Boutoutaou, R.; Kihal, M.; Henni, J.E. Antifungal activity of clove (Syzygium aromaticum L.) essential oil against phytopathogenic fungi of tomato (Solanum lycopersicum L) in Algeria. J. Exp. Biol. Agric. Sci. 2014, 2, 447-454. 
21. Tian, B.L.; Liu, Q.Z.; Liu, Z.L.; Li, P.; Wang, J.W. Insecticidal potential of clove essential oil and its constituents on Cacopsylla chinensis (Hemiptera: Psyllidae) in laboratory and field. J. Econ. Entomol. 2015, 108, 957-961. [CrossRef]

22. Jairoce, C.F.; Teixeira, C.M.; Nunes, C.F.; Nunes, A.M.; Pereira, C.M.; Garcia, F.R. Insecticide activity of clove essential oil on bean weevil and maize weevil. Revista Brasileira de Engenharia Agrícola e Ambiental 2016, 20, 72-77. [CrossRef]

23. Mossa, A.T.H. Green pesticides: Essential oils as biopesticides in insect-pest management. J. Environ. Sci. Tech. 2016, 9, 354. [CrossRef]

24. Vishwakarma, G.S.; Gautam, N.; Babu, J.N.; Mittal, S.; Jaitak, V. Polymeric encapsulates of essential oils and their constituents: A review of preparation techniques, characterization, and sustainable release mechanisms. Polym. Rev. 2016, 56, 668-701. [CrossRef]

25. Maes, C.; Bouquillon, S.; Fauconnier, M.L. Encapsulation of essential oils for the development of biosourced pesticides with controlled release: A review. Molecules 2019, 24, 2539. [CrossRef] [PubMed]

26. Liao, W.; Badri, W.; Dumas, E.; Ghnimi, S.; Elaissari, A.; Saurel, R.; Gharsallaoui, A. Nanoencapsulation of Essential Oils as Natural Food Antimicrobial Agents: An Overview. Appl. Sci. 2021, 11, 5778. [CrossRef]

27. Beirão-da-Costa, S.; Duarte, C.; Bourbon, A.I.; Pinheiro, A.C.; Januário, M.I.N.; Vicente, A.A.; Delgadillo, I. Inulin potential for encapsulation and controlled delivery of Oregano essential oil. Food Hydrocolloid 2013, 33, 199-206. [CrossRef]

28. Hill, L.E.; Gomes, C.; Taylor, T.M. Characterization of beta-cyclodextrin inclusion complexes containing essential oils (transcinnamaldehyde, eugenol, cinnamon bark, and clove bud extracts) for antimicrobial delivery applications. LWT-Food Sci. Technol. 2013, 51, 86-93. [CrossRef]

29. Sun, P.; Zeng, M.; He, Z.; Qin, F.; Chen, J. Controlled release of fluidized bed-coated menthol powder with a gelatin coating. Dry. Technol. 2013, 31, 1619-1626. [CrossRef]

30. Mohammadi, A.; Hashemi, M.; Hosseini, S.M. Nanoencapsulation of Zataria multiflora essential oil preparation and characterization with enhanced antifungal activity for controlling Botrytis cinerea, the causal agent of gray mould disease. Innov. Food Sci. Emerg. Technol. 2015, 28, 73-80. [CrossRef]

31. Froiio, F.; Ginot, L.; Paolino, D.; Lebaz, N.; Bentaher, A.; Fessi, H.; Elaissari, A. Essential oils-loaded polymer particles: Preparation, characterization and antimicrobial property. Polymers 2019, 11, 1017. [CrossRef]

32. Miletaković, S.; Stanković, S.; Krnjajić, S.; Todorović, M.J.; Tomić, V.; Jovanović, R. Economic justification of biological measures for potato tuber moth control. In Proceedings of the IX International Scientific Agriculture Symposium AGROSYM, Jahorina, Bosnia and Herzegovina, 4-7 October 2018; pp. 1030-1033.

33. Tsao, R.; Zhou, T. Antifungal activity of monoterpenoids against postharvest pathogens Botrytis cinerea and Monilinia fructicola. J. Essent. Oil Res. 2000, 12, 113-121. [CrossRef]

34. Adebayo, O.; Dang, T.; Bélanger, A.; Khanizadeh, S. Antifungal studies of selected essential oils and a commercial formulation against Botrytis cinerea. J. Food Res. 2013, 2, 217. [CrossRef]

35. Daniel, C.K.; Lennox, C.L.; Vries, F.A. In vivo application of garlic extracts in combination with clove oil to prevent postharvest decay caused by Botrytis cinerea, Penicillium expansum and Neofabraea alba on apples. Postharvest Biol. Technol. 2015, 99, 88-92. [CrossRef]

36. Popović, T.; Kostić, I.; Milićević, Z.; Gašić, K.; Kostić, M.; Dervišević, M.; Krnjajić, S. Essential oils as an alternative bactericides against soft-rot bacteria, Pectobacterium carotovorum subsp.carotovorum.. In Proceedings of the VIII International Scientific Agriculture Symposium Agrosym 2017, Jahorina, Bosnia and Herzegovina, 5-8 October 2017; pp. 1377-1383.

37. Popović, T.; Milićević, Z.; Iličić, R.; Marković, S.; Oro, V.; Jelušić, A.; Krnjajić, S. Antibacterial activities of essential oils of wild oregano, clove bud, rosemary, peppermint, basil and lemongrass against growth of soft rot bacteria. In Proceedings of the 1st International Symposium: Modern Trends in Agricultural Production and Environmental Protection, Tivat, Montenegro, 2-5 July 2019; pp. 230-242.

38. Popović, T.; Jelušić, A.; Marković, S.; Iličić, R. Characterization of Pectobacterium carotovorum subsp. carotovorum isolates from a recent outbreak on cabbage in Bosnia and Herzegovina. Pesticidi i Fitomedicina 2019, 34, 211-222. [CrossRef]

39. Marković, S.; Stanković, S.; Jelušić, A.; Iličić, R.; Kosovac, A.; Poštić, D.; Popović, T. Occurrence and Identification of Pectobacterium carotovorum subsp. brasiliensis and Dickeya dianthicola Causing Blackleg in some Potato Fields in Serbia. Plant Dis. 2021, 105, 1080-1090. [CrossRef] [PubMed]

40. Marković, S.; Milić Komić, S.; Jelušić, A.; Iličić, R.; Bagi, F.; Stanković, S.; Popović, T. First report of Pectobacterium versatile causing blackleg of potato in Serbia. Plant Dis. 2021, 106, 312. [CrossRef]

41. Adams, R.P. Identification of Essential Oil Components by Gas Chromatography/Mass Spectrometry; Allured Publishing Corporation: Carol Stream, IL, USA, 2007.

42. WHO. Manual on Development and Use of FAO and WHO Specifications for Pesticides. November 2010-Second Revision of the First Edition; FAO: Rome, Italy, 2010; Available online: http:/ / www.fao.org/3/a-y4353e.pdf (accessed on 11 March 2017).

43. Negahban, M.; Moharramipour, S.; Sefidkon, F. Fumigant toxicity of essential oil from Artemisia sieberi Besser against three stored-product insects. J. Stored Prod. Res. 2007, 43, 123-128. [CrossRef]

44. Balouiri, M.; Sadiki, M.; Ibnsouda, S.K. Methods for in vitro evaluating antimicrobial activity: A review. J. Pharm. Anal. 2016, 6, 71-79. [CrossRef]

45. Abbott, W.S. A Method of Computing the Effectiveness of an Insecticide. J. Econ. Entomol. 1925, 18, 265-267. [CrossRef]

46. Jovanović, J.; Krnjajić, S.; Ćirković, J.; Radojković, A.; Popović, T.; Branković, G.; Branković, Z. Effect of encapsulated lemongrass (Cymbopogon citratus L.) essential oil against potato tuber moth Phthorimaea operculella. Crop Prot. 2020, 132, 105109. [CrossRef] 
47. Cox, L. Choosing an Adsorption System for VOC: Carbon, Zeolite or Polymers? Catc Tech. Bull. EPA 456/F-99-004, U.S. Environmental Protec-tion Agency, Research, NC, USA. 1999. Available online: https://www3.epa.gov/ttncatc1/dir1/fadsorb. pdf (accessed on 10 August 2021).

48. De Smedt, C.; Someus, E.; Spanoghe, P. Potential and actual uses of zeolites in crop protection. Pest Manag. Sci. 2015, 71, 1355-1367. [CrossRef]

49. Sopkova, A.; Janokova, E. An insecticide stabilized by natural zeolite. J. Therm. Anal. Calorim. 1998, 53, 477-485. [CrossRef]

50. Kvachantiradze, M.; Tvalchrelidze, E.; Kotetishvili, M.; Tsitsishvili, T. Application of clinoptilolite as an additive for the photostabilization of the Bacillus thuringiensis formulation. In Porous Materials in Environmentally Friendly Processes; Kiricsi, I., Pal-Borbély, G., Nagy, J.B., Karge, H.G., Eds.; Elsevier: Amsterdam, The Netherlands, 1999; pp. 731-735.

51. Froiio, F.; Mosaddik, A.; Morshed, M.T.; Paolino, D.; Fessi, H.; Elaissari, A. Edible polymers for essential oils encapsulation: Application in food preservation. Ind. Eng. Chem. Res. 2019, 58, 20932-20945. [CrossRef]

52. Munteanu, B.S.; Vasile, C. Encapsulation of Natural Bioactive Compounds by Electrospinning-Applications in Food Storage and Safety. Polymers 2021, 13, 3771. [CrossRef] [PubMed]

53. Nguyen, T.T.T.; Le, T.V.A.; Dang, N.N.; Nguyen, D.C.; Nguyen, P.T.N.; Tran, T.T.; Nguyen, Q.V.; Bach, L.G.; Thuy Nguyen Pham, T.D. Microencapsulation of Essential Oils by Spray-Drying and Influencing Factors. J. Food Qual. 2021, 2021, 5525879. [CrossRef]

54. Barros, F.A.; Radünz, M.; Scariot, M.A.; Camargo, T.M.; Nunes, C.F.; de Souza, R.R.; Gilson, I.K.; Hackbart, H.C.; Radünz, L.L.; Oliveira, J.V.; et al. Efficacy of encapsulated and non-encapsulated thyme essential oil (Thymus vulgaris L.) in the control of Sitophilus zeamais and its effects on the quality of corn grains throughout storage. Crop Prot. 2022, 153, 105885. [CrossRef]

55. Tangpao, T.; Krutmuang, P.; Kumpoun, W.; Jantrawut, P.; Pusadee, T.; Cheewangkoon, R.; Sommano, S.R.; Chuttong, B Encapsulation of Basil Essential Oil by Paste Method and Combined Application with Mechanical Trap for Oriental Fruit Fly Control. Insects 2021, 12, 633. [CrossRef]

56. Kouassi, K.H.S.; Bajji, M.; Jijakli, H. The control of postharvest blue and green molds of citrus in relation with essential oil-wax formulations, adherence and viscosity. Postharvest Biol. Technol. 2012, 73, 122-128. [CrossRef]

57. Chaieb, K.; Hajlaoui, H.; Zmantar, T.; Kahla-Nakbi, A.B.; Rouabhia, M.; Mahdouani, K.; Bakhrouf, A. The chemical composition and biological activity of clove essential oil, Eugenia caryophyllata (Syzigium aromaticum L. Myrtaceae): A short review. Phytother. Res. 2007, 21, 501-506. [CrossRef] [PubMed]

58. Jafri, H.; Ansari, F.A.; Ahmad, I. Prospects of essential oils in controlling pathogenic biofilm. In New Look to Phytomedicine; Khan, M.S.A., Ahmad., I., Chattopadhyay, D., Eds.; Academic Press: Cambridge, MA, USA, 2019; pp. 203-236.

59. Santos-Gomes, P.C.; Fernandes-Ferreira, M. Organ-and season-dependent variation in the essential oil composition of Salvia officinalis L. cultivated at two different sites. J. Agric. Food Chem. 2001, 49, 2908-2916. [CrossRef]

60. Hyldgaard, M.; Mygind, T.; Meyer, R.L. Essential oils in food preservation: Mode of action, synergies, and interactions with food matrix components. Front. Microbiol. 2012, 3, 12. [CrossRef]

61. Huang, Y.; Ho, S.H.; Lee, H.C.; Yap, Y.L. Insecticidal properties of eugenol, isoeugenol and methyleugenol and their effects on nutrition of Sitophilus zeamais Motsch. (Coleoptera: Curculionidae) and Tribolium castaneum (Herbst)(Coleoptera: Tenebrionidae). J. Stored Prod. Res. 2002, 38, 403-412. [CrossRef]

62. Kafle, L.; Shih, C.J. Toxicity and repellency of compounds from clove (Syzygium aromaticum) to red imported fire ants Solenopsisinvicta (Hymenoptera: Formicidae). J. Econ. Entomol. 2013, 106, 131-135. [CrossRef] [PubMed]

63. Lopez-Reyes, J.G.; Spadaro, D.; Prelle, A.; Garibaldi, A.; Gullino, M.L. Efficacy of plant essential oils on postharvest control of rots caused by fungi on different stone fruits in vivo. J. Food Prot. 2013, 76, 631-639. [CrossRef]

64. Elshafie, H.S.; Mancini, E.; Camele, I.; De Martino, L.; De Feo, V. In vivo antifungal activity of two essential oils from Mediterranean plants against postharvest brown rot disease of peach fruit. Ind. Crop Prod. 2015, 66, 11-15. [CrossRef]

65. Servili, A.; Feliziani, E.; Romanazzi, G. Exposure to volatiles of essential oils alone or under hypobaric treatment to control postharvest gray mold of table grapes. Postharvest Biol. Technol. 2017, 133, 36-40. [CrossRef]

66. Pathirana, H.N.K.S.; Wimalasena, S.H.M.P.; De Silva, B.C.J.; Hossain, S.; Heo, G. Antibacterial activity of clove essential oil and eugenol against fish pathogenic bacteria isolated from cultured olive flounder (Paralichthys olivaceus). Slov. Vet. Res. 2019, 56, 31-38. [CrossRef]

67. Hajian-Maleki, H.; Baghaee-Ravari, S.; Moghaddam, M. Efficiency of essential oils against Pectobacterium carotovorum subsp. carotovorum causing potato soft rot and their possible application as coatings in storage. Postharvest Biol. Technol. 2019, 156, 110928. [CrossRef] 